DOI https://doi.org/10.32837/app.v0i64.195

УДК 327:332.14(560+477)

Akhmedova E. (Mariupol State University)

ORCID ID: https://orcid.org/0000-0003-0916-3677

\title{
THE IMPORTANCE OF THE BLACK SEA SECURITY COOPERATION BETWEEN THE REPUBLIC OF TURKEY AND UKRAINE AND THE EUROPEAN UNION BLACK SEA SYNERGY SECURITY SYSTEM
}

*Elmira Akhmedova - PhD Student, Mariupol State University, Ukraine (129-a pr. Budivelnykiv, Mariupol, Ukraine).

\section{Abstract}

The article examines the content, main points, and objectives of the European Union 2007 Regional Cooperation Initiative Black Sea Synergy, issues that lie within the common interests of the Black Sea states as well as potential challenges to the regional stability in the Black Sea region. It also examines the basic legal documents which are an integral part of the European Union's legal international cooperation in the framework of the Black Sea Initiative. It also researches the national interests of Ukraine, the main directions and the importance of building strategic relations between Ukraine and the Turkish Republic in terms of ensuring regional stability in the Black Sea region.

The article researches the importance of the Black Sea region in building security and stability in Europe and Asia, international legal documents between the parties in building regional Black Sea security and strategic interests of Ukraine in cooperation with the Republic of Turkey in the Black Sea security. It is stressed that the Black Sea Region is one of the main factors in building security and stability in Europe and Asia. Along with other issues in the region, ethnic conflicts, ongoing state-building processes, possessing the vast natural resources, the strategic significance of transportation corridors means that the region is an extremely important and sensitive area.

Special attention is given to an analysis of bilateral relations between the Republic of Turkey and Ukraine that are becoming more strategic considering Turkey's special role in the Black Sea region and its complementary role for the European Union policy in the region. It states that the dramatic change in the geopolitical situation in the region in 2014 led to the revision of Ukraine's foreign 
policy towards the Republic of Turkey. The Republic of Turkey has moved to the top of Ukraine's foreign policy priorities following the loss of Crimea, the conflict in eastern Ukraine and the general aggravation of the security situation in the Black Sea region.

The article concludes that the Black Sea Synergy remains declarative as it does not provide a clear explanation of the EU's political position on the Black Sea issues. It requires very specific action to prevent real threats. In the current situation, Ukraine can only achieve its strategic goal through cooperation within the framework of regional associations of different plans.

Keywords: regional security, Black Sea Synergy, the European Union, Republic of Turkey, Ukraine.

Problem Statement. Ongoing and potential military conflicts between the regional states of the Black Sea region constitute the basic threats to regional stability and security of the whole European continent as well as the European Union. In this regard, in 2007 the European Union has developed the "Black Sea Synergy" initiative with a number of concrete steps looking at the areas like transport, energy, the environment, maritime management, fisheries, migration, the fight against organized crime, the information society and cultural cooperation etc. The European Union seeks to increase cooperation among the countries surrounding the Black Sea. Specifically it aims to: stimulate democratic and economic reforms; support stability and promote development; focus on practical projects in areas of common concern; respond to opportunities and challenges through coordinated actions in a regional framework; develop a climate more conducive to the solution of conflicts in the region. The Republic of Turkey and Ukraine are becoming potential alliances of the European Union in the matter of providing stability in the Black Sea Region that has been extensively on its priority agenda since Romania and Bulgaria's membership in 2007.

Analysis of recent reseach and publications. The studied issue is relatively new and not widely reflected in the studies of foreign and domestic specialists. It is generally covered in media sources, legal documents related to Black Sea Security issues, the European Union Security Strategies, the European Union Council Conclusions, Declarations etc that help to understand the main points of the issue.

The purpose of the article is to research the current state of international legal cooperation between the Republic of Turkey, Ukraine and the European Union in Black Sea Security initiatives and related European Union Programs. 
The following tasks are being researched to achieve the task of the article:

- to research the importance of the Black Sea region in building security and stability in Europe and Asia;

- analysis of the European Union regional initiative «Black Sea Synergy» 2007 and its meaning for developing and building multilateral security cooperation in the Black Sea region;

- to research and study international legal documents between the European Union, Ukraine and the Republic of Turkey concluded in the sphere of Black Sea regional security cooperation;

- to research the strategic interests of Ukraine in the Black Sea security cooperation with the Republic of Turkey and the European Union;

- to research the impact of the European integration processes on strengthening relations between the European Union and the Republic of Turkey within the framework of Black Sea Synergy.

Description of the main material. The Black Sea Region (BSR) is one of the main factors in building the security and stability in Europe and Asia. In addition to the numerous other issues in the region, ethnic conflicts, ongoing state building processes, the presence of vast natural resources, and strategic transport and energy corridors mean that the region is an extremely important and sensitive area. Hard security issues are still the basic problem in the region, no matter whether they are caused by ethnic, religious or any other differences between peoples and states, or by border problems. Some of the states in the region are still weak and disorganized, some of them could easily become failed states. A lot of studies state that their weakness makes the region one of the global hot spots for threats such as terrorism, the proliferation of weapons of mass destruction, and illegal trafficking in drugs, arms and human beings. Thus these fragile states have the potential to affect the security of other regional actors and of nearby European Union (EU) states. In some of the states in the region there is a tendency to favour authoritarianism and to glorify military power. This exacerbates the threat perceptions already in existence and has an adverse effect on regional security (Security in the Black Sea Region. Policy Report II, 2010).

Black Sea Region has been extensively on the agenda of the EU since Romania and Bulgaria's membership in 2007. In 2008 the EU created "Black Sea Synergy" (BSS) (Black Sea Synergy, 2019) as a regional initiative in order to develop cooperation in the region in certain areas such as energy, transport and environment. Countries that take part in the Black 
Sea Synergy, Armenia, Azerbaijan, Georgia, Moldova, and Ukraine are also part of "Eastern Partnership" which is another initiative simultaneously established with "Black Sea Synergy" as a part of the wider policy "European Neighbourhood Policy" (ENP) (European Neighborhood Policy, 2016).

The main characteristics of the Black Sea Synergy as determined by the 2007 Black Sea Synergy Communication and its implementation during the years are the following: (i) Black Sea Synergy is a coherent, long-term initiative. It complements the EU's bilateral activities in the Black Sea region and facilitates more sector-oriented EU support for the region. (ii) The initiative is inclusive in that participation is open to states in the wider Black Sea region. Key elements of the initiative include building confidence, fostering regional dialogue and achieving tangible results for states and citizens in the region. (iii) Encouraging a bottom-up approach to project development, identifying and supporting the needs, priorities and aims of partners in the region, and what they want to do together are fundamental for the Black Sea Synergy. The countries in question implement the projects and measures developed under the Black Sea Synergy umbrella on a voluntary basis, at regional level and through different types of interaction (cross-border, local authorities, civil society, intergovernmental, etc.). Stronger links with other EU initiatives, policies and strategies are also reflected as specific for the Black Sea Synergy, in particular with the EU Strategy for the Danube Region (The EU Strategy for the Danube Region. A united response to common challenges, 2011), the Integrated Maritime Policy (The Integrated Maritime Policy, 2019) and the EU Maritime Security Strategy (European Union Maritime Security Strategy. Responding Together to Global Challenges). The 2018 EU Communication on 'Connecting Europe and Asia - Building Blocks for an EU Strategy (Joint Communication to the European Union, The Council, the European Economic and Social Committee, the Committee of the Regions and The European Investment Bank. Connecting Europe and Asia - Building Blocks for an EU Strategy, 2018) refers in particular to the 'bridging role of the Black Sea basin' and to interconnectivity both within the EU (East-West, North-South from the Baltic Sea to the Black Sea) and between continents (Europe and Asia) (Joint Staff Working Document. Black Sea Synergy: review of a regional cooperation initiative - period 2015-2018, 2019).

On June 172019 the Council adopted conclusions on the EU's engagement to the Black Sea regional cooperation (Council Conclusions 
on the EU's Engagement to the Black Sea Regional Cooperation, 2019). The Council reaffirms its long-standing commitment to fostering prosperity, stability, and resilience in the Black Sea area. It emphasises the increasing strategic importance of the Black Sea area for the EU, and calls for enhanced EU involvement in the regional cooperation, with the Black Sea Synergy initiative at its basis. In particular, it highlights the importance of harnessing the new opportunities for economic development, resilience and connectivity in the region and beyond. The Council remains concerned about the security challenges in the Black Sea area. In this context, it reiterates that respect for international law, including the principles of independence, sovereignty and territorial integrity, the United Nations Convention on the Law of the Sea, including freedom of navigation, as well as EU policy decisions and its non-recognition policy on the illegal annexation of Crimea, are fundamental to the EU's approach to regional cooperation in the Black Sea areas (Council Conclusions on the EU's Engagement to the Black Sea Regional Cooperation, 2019). In this sense, the bilateral relations between Ukraine and Republic of Turkey (TR) is getting more strategic considering its special role in the region and complementary role for the EU policies in the region. TR is a regional actor that cannot be ignored and has an indispensable role for the stability of the region and EU accession process still remains the main anchor of TR's inclusion in the Black Sea Synergy initiative (Yazgan, 2017, s. 74).

In terms of regional cooperation, Ukraine is positioned by the EU as one of the key countries in Eastern Europe. In particular, Ukraine plays a key role in the framework of the EU Eastern Partnership initiative, which is seen as a further stage of integration between the EU and Eastern European countries. Model of EU-Ukraine relations is proposed as an example for other recipient countries (Azerbaijan, Belarus, Armenia, Georgia and Moldova) (The European Union Policy Toward Ukraine) Nevertheless, The Black Sea Synergy remains declarative as it does not provide a clear explanation of the EU's political position on the Black Sea issues. It requires very specific action to prevent real threats. In the current situation, Ukraine can only achieve its strategic goal through cooperation within the framework of regional associations of different plans. Particular attention should be paid to energy security, the issue of resolving frozen issues and resolving existing conflicts. A lot of studies say that it is necessary to intensify the discussion of the security issue of the energy transit infrastructure especially in the conditions of instability 
in order to determine the format of international cooperation in this field (Снигір, 2008).

As it was mentioned above TR is another significant regional partner of the EU in the "Black Sea Synergy" initiative. As mentioned in the 2007 communication of the European Commission "...broad EU policy towards the region is already set out in the pre-accession strategy with Turkey, the ENP and the Strategic Partnership with Russia." TR's inclusion in the initiative is mainly dependent on its EU pre-accession process. In other words, TR's EU process complements "Black Sea Synergy" and deterioration of TR's relations with the EU may also hamper the EU's "Black Sea Synergy" / ENP objectives. Currently the EU-Turkey relations face one of the most severe crises. Recent European Parliament decision on temporarily suspension of accession talks with TR indicates the crisis and therefore, deteriorating relations between TR and the EU have the risk of mitigating the opportunities for cooperation in the Black Sea region (Yazgan, 2017).

As for the bilateral relations between TR and Ukraine we can conclude that until recently, the "strategic partnership" between the parties existed primarily as an attribute of diplomatic rhetoric rather than a meaningful format of bilateral relations. The dramatic change in the geopolitical situation in the region in 2014 led to a revision of Ukraine's policies towards TR. TR moved to the top of Ukraine's foreign policy priorities following the loss of Crimea, the conflict in eastern Ukraine, and the aggravation of the security situation in the Black Sea region in general. A rapprochement with Ukraine is one of the components of Ankara's return to its pro-European course. As of today, Ukraine's interests regarding TR are in the following areas: 1) Security, including security in the Black Sea region, and Turkey's possible participation in establishing of the deoccupation mechanism for Crimea (the Geneva plus format); 2) Economic, in the context of attracting financial aid for the stabilization and restoration of Ukraine, as well as strengthening trade relations with Turkey; 3) Energy, including obtaining TR's permission for passage of tankers with liquefied natural gas (LNG) through the Bosphorus-, and the construction of an LNG terminal (following negotiations) and interconnectors; 4) Humanitarian, such as cooperation regarding internally displaced persons, in particularthe Crimean Tatars; establishing ties between the Crimean Tatar minority in Ukraine and the Crimean Tatar diaspora in TR in order to advocate Ukraine's interests in TR (Foreign Policy Audit: Ukraine - Turkey, 2016). 
Some studies say that in order to achieve the most desirable scenario for the development of trilateral relations in the security sphere, Ukraine should consider the possibility of TR's involvement in the development of a joint security strategy for the Black Sea region and the coordination of joint efforts to maintain stability (such as the Turkish Caucasus Stability and Cooperation Platform initiative, proposed after the 2008 Russo-Georgian War). It is also necessary to intensify cooperation with TR in the field of joint exercises, exchange of experience between experts of countries, and joint consultations, training and workshops on security sector reforms and army modernization. Study the experience of TR in its fight against some terrorist (Kurdish) organizations and post-conflict regulation (e.g., the settlement of former military personnel in the Kurdish areas) and intensify negotiations on establishing joint ventures to deepen military industrial cooperation etc (Foreign Policy Audit: Ukraine - Turkey, 2016). Moreover, other studies say Ukraine needs to insist on closer involvement of the EU and more involvement of NATO in the process of ensuring regional security - infrastructure in times of instability, navigation and tanker shipping. Ukraine should also take the initiative of coordinating regional efforts in the framework of the energy transit activities of the EU's eastern neighbors in line with the recently announced proposals for the next stage of Black Sea Synergy cooperation and Ukraine's own initiatives to create an energy transit space (Снигір, 2008, c. 200). As for strategic relations in the security sphere some number of important meetings has already taken place within the period of 2015 - 2016, including the first formal meeting of President of Ukraine P. Poroshenko and President of TR R. T. Erdogan in March 2015 and the next, in March 2016. In addition to supporting the territorial integrity of Ukraine, they underlined the significant potential of TR in facilitating the stabilization of the situation in Ukraine and noted the prospect of involvement of TR construction companies in the reconstruction of devastated regions of Ukraine. The expansion of TR's zone of responsibility is explained not only by the desire to secure its security, but to project it, its self-perception as a global power, as well as its confrontation with Russia - create a completely new format of the system security in the region that Ukraine needs to align with its interests and policies. Of course, the security of the Black Sea region is also important for Turkish foreign policy, however, the parties didn't sign any legal documents in Black Sea Security sphere and didn't make any concrete programs on this issue (Foreign Policy Audit: Ukraine - Turkey, 2016).

In March 2016 P. Poroshenko named the key achievement of the fifth meeting of the High-level Strategic Council between Ukraine and TR, which was chaired by the two heads of state, the decision to deepen the 
strategic alliance between Ukraine and TR, in particular - cooperation in the field of security and defense. The outcome of the Fifth Session of the High Level Strategic Council between Ukraine and the TR was signed by a number of documents. Thus, P. Poroshenko and R. T. Erdogan signed a joint Declaration on deepening the strategic partnership between Ukraine and the Republic of Turkey (Joint Declaration on deepening the strategic partnership between Ukraine and the Republic of Turkey, 2009). It was also signed a Protocol on Cooperation between the National Security and Defense Council and the Secretariat of the National Security and Defense Agency in TR (Україна та Туреччина поглиблюватимуть стратегічне партнерство задля безпеки в Чорноморському регіоні - підсумки зустрічі президентів, 2016). The recent statement of Ukrainian Foreign Minister P. Klimkin at a joint press conference with Turkish Foreign Minister M. Cavusoglu in Odesa leads one to believe that Ukraine and Turkey will do some important steps to provide security in the Black Sea region. The minister said that Turkey plans in the coming years to provide special assistance to the Armed Forces of Ukraine and noted that the military and technical sectors of both countries continue to move towards synergy and will sign some legal agreements on joint development of some armed systems (Україна та Туреччина поглиблюватимуть стратегічне партнерство задля безпеки в Чорноморському регіоні підсумки зустрічі президентів,2016). In general, the Black Sea Synergy remains declarative as it does not provide a clear explanation of the EU's political position on the Black Sea issues. It requires very specific action to prevent real threats.

\section{Conclusions}

The analysis of the implementation of the EU Black Sea Synergy initiative leads to the following conclusions:

- The Black Sea Synergy remains declarative as it does not provide a clear explanation of the EU's political position on the Black Sea issues. It requires very specific action to prevent real threats. In the current situation, Ukraine can only achieve its strategic goal through cooperation within the framework of regional associations of different plans. Particular attention should be paid to energy security, the issue of resolving frozen issues and resolving existing conflicts it is necessary to intensify the discussion of the security issue of the energy transit infrastructure (especially in the conditions of instability) in order to determine the format of international cooperation in this field. Given that this issue has already been discussed in the EU and NATO, Ukraine needs to insist on closer involvement of the EU; 
- the lack of attention of Black Sea Synergy initiators in addressing key problematic issues in the region significantly impede cooperation as well as the lack of funds for project implementation in the vast majority of countries of the region. The development of sectoral cooperation continues, for the most part, independently of the EU initiative due to already existing models of cooperation in the region;

- national interests and security of Ukraine in the Black Sea Region require very concrete action to prevent real threats. Ukraine can only achieve its strategic goal through cooperation within regional unions. Significant potential of Turkey in facilitating the stabilization of the situation in Ukraine can create a completely new format of the system security in the region that Ukraine needs to align with its interests and policies as the security of the Black Sea region is also important for Turkish foreign policy.

\section{Лimepamypa:}

Снигір, О. В. (2008). Відносини України та ЄС у контексті формування безпекового сегмента чорноморської політики Евросоюзу. Стратегічні nрiоритети, 3 (8), 192-201. URL: <http://sp.niss.gov.ua/content/articles/ files/24-1445001428.pdf>.

Україна та Туреччина поглиблюватимуть стратегічне партнерство задля безпеки в Чорноморському регіоні - підсумки зустрічі президентів (2016). URL: <https://mfa.gov.ua/ua/news-feeds/foreign-offices-news/45522ukrajina-ta-turechchina-pogliblyuvatimuty-strategichne-partnerstvozadlya-bezpeki-v-chornomorsykomu-regioni--pidsumki-zustrichiprezidentiv>.

Black Sea Synergy (2019). URL: <https://eeas.europa.eu/diplomaticnetwork/black-sea-synergy/346/black-sea-synergy_en>.

Council Conclusions on the EU's Engagement to the Black Sea Regional Cooperation (2019). URL: <https://www.consilium.europa.eu/media/39779/st10219en19.pdf>.

European Neighborhood Policy (ENP) (2016). URL: <https://eeas.europa. eu/printpdf/330_en>.

European Union Maritime Security Strategy. Responding Together to Global Challenges. URL: <https://ec.europa.eu/maritimeaffairs/sites/ maritimeaffairs/files/leaflet-european-union-maritime-security-strategy en.pdf>.

Foreign Policy Audit: Ukraine - Turkey (2016). URL: <http:/ / prismua.org/ wp-content/uploads/2016/04/Aud_Ukr_Turk_01_32_eng-2.pdf>. 
Joint Communication to the European Union, The Council, the European Economic and Social Committee, the Committee of the Regions and The European Investment Bank. Connecting Europe and Asia - Building Blocks for an EU Strategy (2018). URL: <https://eeas.europa.eu/sites/eeas/files/ joint_communication_-_connecting_europe_and_asia_-_building_blocks_ for_an_eu_strategy_2018-09-19.pdf>.

Joint Declaration on deepening the strategic partnership between Ukraine and the Republic of Turkey (2009). URL: <https:/ / turkey.mfa.gov.ua/en/page/ open/id/780>.

Joint StaffWorking Document. Black Sea Synergy: review of a regional cooperation initiative - period 2015-2018 (2019). URL: <https://eeas.europa.eu/ diplomatic-network/black-sea-synergy/346/black-sea-synergy_en>.

Security in the Black Sea Region. Policy Report II (2010). URL: <https:/ / www.files.ethz.ch/isn/115942/2010_PolicyReport-2.pdf>.

The EU Strategy for the Danube Region. A united response to common challenges (2011). URL: <https:/ / ec.europa.eu/regional_policy/sources/docgener/ panorama/pdf/mag37/mag37_en.pdf>.

The European Union Policy Toward Ukraine. URL: <https:/ / ukraine-eu.mfa. gov.ua/en/ukraine-eu/ eu-policy>.

The Integrated Maritime Policy (2019). URL: <http:/ / www.europarl.europa. $\mathrm{eu} / \mathrm{ftu} / \mathrm{pdf} / \mathrm{en} /$ FTU_3.3.8.pdf>.

Yazgan, H. (2017). Black Sea Synergy: Success or Failure for the European Union? Marmara University Journal of Political Science, Cilt 5, Özel Sayı, Nisan, 67-78. URL: <https:/ / dergipark.org.tr/download/article-file/301433>.

\section{References:}

Black Sea Synergy (2019). URL: <https://eeas.europa.eu/diplomaticnetwork/black-sea-synergy/346/black-sea-synergy_en>.

Council Conclusions on the EU's Engagement to the Black Sea Regional Cooperation (2019). URL: <https://www.consilium.europa.eu/media/39779/st10219en19.pdf>.

European Neighborhood Policy (ENP) (2016). URL: <https:// eeas.europa. eu/printpdf/330_en>.

European Union Maritime Security Strategy. Responding Together to Global Challenges. URL: <https://ec.europa.eu/maritimeaffairs/sites/ maritimeaffairs/files/leaflet-european-union-maritime-security-strategy en.pdf>. 
Foreign Policy Audit: Ukraine - Turkey (2016). URL: <http:/ / prismua.org/ wp-content/uploads/2016/04/Aud_Ukr_Turk_01_32_eng-2.pdf>.

Joint Communication to the European Union, The Council, the European Economic and Social Committee, the Committee of the Regions and The European Investment Bank. Connecting Europe and Asia - Building Blocks for an EU Strategy (2018). URL: <https://eeas.europa.eu/sites/eeas/files/ joint_communication_-_connecting_europe_and_asia_-_building_blocks_ for_an_eu_strategy_2018-09-19.pdf>.

Joint Declaration on deepening the strategic partnership between Ukraine and the Republic of Turkey (2009). URL: <https:/ / turkey.mfa.gov.ua/en/page/ open/id/780>.

Joint StaffWorking Document. Black Sea Synergy: review of a regional cooperation initiative - period 2015-2018 (2019). URL: <https://eeas.europa.eu/ diplomatic-network/black-sea-synergy/346/black-sea-synergy_en>.

Security in the Black Sea Region. Policy Report II (2010). URL: <https://www.files.ethz.ch/isn/115942/2010_PolicyReport-2.pdf>.

Sny`gir, O. V. (2008). Vidnosy`ny`Ukrayiny` ta YeS u konteksti formuvannya bezpekovogo segmenta chornomors`koyi polity`ky` Yevrosoyuzu [EU-Ukraine relations in the context of forming a safe segment of the EU's Black Sea policy]. Strategichni priory 'tety [Strategic Priorities], 3 (8), 192-201. URL: <http:/ / sp.niss.gov.ua/content/articles/ files/24-1445001428.pdf>. [in Ukrainian].

The EU Strategy for the Danube Region. A united response to common challenges (2011). URL: <https:/ / ec.europa.eu/regional_policy/sources/docgener/ panorama/pdf/mag37/mag37_en.pdf>.

The European Union Policy Toward Ukraine. URL: <https:/ / ukraine-eu.mfa. gov.ua/en/ukraine-eu/ eu-policy>.

The Integrated Maritime Policy (2019). URL: <http:/ / www.europarl.europa. $\mathrm{eu} / \mathrm{ftu} / \mathrm{pdf} / \mathrm{en} /$ FTU_3.3.8.pdf>.

Ukrayina ta Turechchy'na pogly blyuvaty'mut' strategichne partnerstvo zadlya bezpeky` $v$ Chornomors `komu regioni - pidsumky`zustrichi prezy dentiv [Ukraine and Turkey will deepen strategic partnership for security in Black Sea region - results of presidents' meeting] (2016). URL: <https://mfa.gov.ua/ua/news-feeds/foreign-offices-news/45522ukrajina-ta-turechchina-pogliblyuvatimuty-strategichne-partnerstvozadlya-bezpeki-v-chornomorsykomu-regioni--pidsumki-zustrichiprezidentiv>. [in Ukrainian]. 
Yazgan, H. (2017). Black Sea Synergy: Success or Failure for the European Union? Marmara University Journal of Political Science, Cilt 5, Özel Sayı, Nisan, 67-78. URL: <https:/ / dergipark.org.tr/download/article-file/301433>.

\section{Анотація}

Ахмедова Е. Важливість співробітництва в сфері Чорноморської безпеки між Турецькою Республікою та Украйною та системи безпеки Eвропейсъкого Союзу «Black Sea Synеrgy». - Стаття.

Стаття аналізує зміст, основні положення та изілі регіональної ініціативи Європейського Союзу «Black Sea Synеrgy» 2007 року; питання, що лежать у площині спільних інтересів Чорноморських країн, а також потениійні виклики регіональній стабільності Чорноморського регіону. Досліджено основні правові документи, щзо є невід'ємною частиною правового міжнародного співробітництва Європейського Союзу з країнами Чорноморського басейну в рамках Чорноморської ініціативи. Стаття також досліджує національні інтереси України, основні напрямки та актуальність побудови стратегічних відносин між Україною та Турецькою Республікою в питані забезпечення регіональної стабільності в Чорноморському регіоні.

У статті також досліджено важливість Чорноморського регіону у побудові безпеки та стабільності в Європі та Азії, міжнародно-правові документи між зацікавленими сторонами та стратегічні інтереси Украйни у співпраці з Турецькою Республікою у сорері безпеки Чорного моря. Підкреслюється, що Чорноморський регіон є одним з головних факторів у розвитку безпеки та стабільності в Європі та Азії. Поряд з усіма проблемами в регіоні, етнічними конфліктами, державотворчими процесами, щзо наразі тривають, володіння величезними природними ресурсами та стратегічне значення транспортних коридорів роблять регіон надзвичайно важливою та чутливою територією.Особлива увага приділяється аналізу двосторонніх відносин між Турецькою Республікою та Україною, які наразі набувають стратегічного значення враховуючи особливу роль Турецької Республіки В Чорноморському регіоні та регіональній політиці Свропейського Союзу. В статті ӥдеться про те, щуо різкі зміни геополітичної ситуації В регіоні 82014 році призвели до перегляду зовнішньої політики України щуодо Турецької Республіки, а Турецька Республіка перейшла до першочергових пріоритетів зовнішнъої політики України після втрати Криму, конфлікту на сході України та загального загострення ситуації з безпекою $b$ Чорноморському регіоні.

Ключові слова: регіональна безпека, Чорноморська Синергія, Європейський Союз, Турецька Республіка, Украйна. 